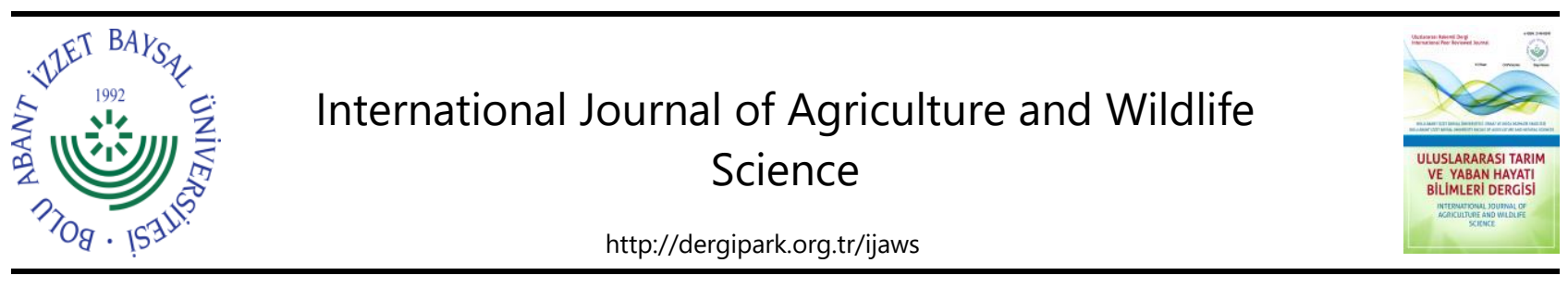

Research Article

\title{
The Effect of Plant Growth Promoting Rhizobacteria on Root Growth in Bread Wheat (Triticum aestivum L.)
}

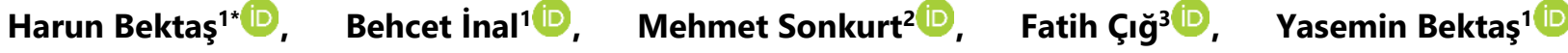 \\ ${ }^{1}$ Siirt University, Faculty of Agriculture, Department of Agricultural Biotechnology, Siirt, Turkey \\ ${ }^{2}$ Agriculture and Rural Development Support Institution (TKDK), Mardin, Turkey \\ ${ }^{3}$ Siirt University, Faculty of Agriculture, Department of Field Crops, Siirt, Turkey
}

Received: 11.01.2021 Accepted: 17.05.2021

\section{Keywords:}

Bread wheat, ACC deaminase, root system, root length, PGPR

*Corresponding author bektasharun@gmail.com

Abstract. Bread wheat (Triticum aestivum L.) is the most produced cool-season cereal in the world and meets about $20 \%$ of our daily caloric intake. Climate change negatively affects grain yield, it is, therefore, necessary to improve climate-resilient wheat crops. It is a known fact that subsoil parameters are not mostly included in the breeding selection criteria due to some technical limitations. For this reason, it is essential to examine the root system, which has a fundamental role in drought tolerance, for morphological, anatomical, physiological, and architectural aspects, to understand the genetic mechanisms of these traits and to determine breeding strategies. In this study, the seeds of two different bread wheat varieties were inoculated by three different plant growth-promoting rhizobacteria (PGPR), which synthesize the ACC deaminase enzyme. When the results were evaluated, significant differences were observed between varieties and bacterial applications for the total root length and root growth angle. As a result of the study, it was observed that all three bacteria species had a positive effect on root development. Brevibacillus choshinensis was the most effective inoculation on total root length in Gerek $79(95.4 \mathrm{~cm})$, while it was Arthrobacter agilis in Bezostaja 1 $(62.8 \mathrm{~cm})$. We suggest that plant growth-promoting rhizobacteria have a positive effect on wheat root development and a detailed analysis of this effect should be carried out with future studies.
\end{abstract}

\section{Bitki Gelişimini Teşvik Edici Rizobakterilerin Ekmeklik Buğdayda (Triticum aestivum L.) Kök Gelişimine Etkisi}

\section{Anahtar kelimeler:}

ACC deaminaz, ekmeklik buğday, kök sistemi, kök uzunluğu, PGPR
Özet. Ekmeklik buğday (Triticum aestivum), dünya üzerinde en fazla üretimi yapılan ve günlük kalori intiyacımızın yaklaşık \%20'sini karşılayan bir serin iklim tahılıdır. İklim değişimi buğdayın verim değerlerini negatif yönde etkilemektedir. Islah çalışmalarında toprak altı parametrelerinin bazı teknik zorluklar nedeniyle çoğunlukla sürece dahil edilemediği bilinen bir olgudur. Bu nedenle kuraklık toleransında temel bir role sahip olan kök sistemini morfolojik, anatomik, fizyolojik ve mimari yönden incelemek, bu özelliklerin genetik mekanizmalarını anlamak ve yetiştirme stratejilerini belirlemek için esastır. Bu çalışma ile iki farklı ekmeklik buğday çeşidinin tohumlarına, ACC deaminaz enzimi sentezleme özelliğine sahip bitki gelişimini tetikleyici üç farklı rizobakteri (PGPR) inoküle edilmiştir. Sonuçlar incelendiğinde, toplam kök uzunluğu ve kök büyüme açısı parametrelerinde çeşitler ve bakteri uygulamaları arasında anlamlı farklılıklar gözlenmiştir. Çalışma sonucunda her üç bakteri türünün de kök gelişimi üzerine pozitif etkisinin olduğu saptanmıştır. Brevibacillus choshinensis Gerek 79 'da $95.4 \mathrm{~cm}$ toplam kök uzunluğu ile en etkili inokülasyon iken, Bezostaja 1'de Arthrobacter agilis $62.8 \mathrm{~cm}$ ile en etkili inokülasyon olmuştur. Bitki gelişimini teşvik edici bakterilerin buğday kök gelişimine pozitif yönde etkisinin olduğu ve gelecekte yapılacak çalışmalar ile bu etkinin detaylı analizlerinin yapılmasını öneriyoruz. 


\section{INTRODUCTION}

Three members of the Triticeae tribe, bread wheat (Triticum aestivum L.), corn (Zea mays L.), rice (Oryza sativa L.), and grain legumes represent the main food groups. Wheat can be cultivated on all continents except Antarctica. Since the world population is expected to exceed 9 billion by 2050, the yields of all crops, especially wheat, should increase by at least $50 \%$. Wheat has the highest cultivation area among cool-season grains with more than 765 million metric tons of production as of 2019 (FAOSTAT, 2019). Wheat, alone, meets approximately $20 \%$ of the global calorie need. It is not feasible to create new agricultural land, and available lands are under the threat of salinity, flood, drought, and erosion (Döös, 2002). The global average wheat yield is about $2780 \mathrm{~kg}$ per hectare and it is $3547 \mathrm{~kg}$ in Turkey (FAOSTAT, 2019). These values are far below the genetic yield potential of wheat. The significant increase in the mean temperature due to climate change has shown that drought and high temperature will be the biggest obstacles to agricultural production (Trnka et al., 2015). Simulation studies have shown that the yield increase will be about $10 \%$ lower than the expected values due to rising temperatures and drought stress (Reeves et al., 2016). Turkey is in one of the most affected regions by climate change and drought, and urgently needs drought-tolerant wheat varieties (Trnka et al., 2015). Developing high-yielding varieties that are tolerant to drought or high-temperature stresses will be possible by understanding the physiological and morphological responses of plants to stress conditions.

While the responses of aboveground plant organs to stress factors are investigated in vast detail in wheat prebreeding studies, the root system, which is one of the most important organs for drought tolerance, has been mostly ignored due to technical difficulties. Since a well-developed root system reaches deeper and wider soil areas, it reduces the effects of low to moderate stresses by improved water and mineral uptake. The root system is the first organ to perceive the water deficit in the soil, and by sending hormonal signals to the stem, it can cause the plants to close the stomata, thus slowing down or completely halting photosynthesis. In the studies conducted with rice (Oryza sativa), the Dro1 (Deeper rooting 1) gene, which allows the roots to grow at a steeper angle and deeper by making the roots more responsive to gravity, was cloned and it was reported that drought resistance was increased with the effect of this gene (Uga et al., 2011). Manschadi et al. (2006), calculated that for every millimeter of extra water absorbed by the roots, yield increased by $55 \mathrm{~kg} \mathrm{~h}^{-1}$. The effect of roots on drought tolerance has been proven many times since the pioneering works of Weaver (1926), Richards and Passioura (1981), Reynolds et al. (2007), and Passioura (1983; 2012). Considering all these factors, it is important to investigate plant root characters, increase the number and lengths of roots, total root length, and rooting depth, and find genes that determine root system architecture.

It has been known that Plant Growth Promoting Rhizobacteria (PGPR) contributes to plant growth (Biçer et al., 2020). They can achieve this function by decreasing ethylene synthesis or increasing the synthesis of auxin and cytokinins (Glick et al., 2007). 1-aminocyclopropane-1-carboxylic acid (ACC), a bacterial deaminase enzyme, can be synthesized by many microorganisms and inhibits ethylene biosynthesis. This enzyme prevents or reduces ethylene formation by breaking down ACC, which is a precursor in ethylene biosynthesis. Thus, as ethylene level decreases, the plant leaves do not receive stress signals and continue to grow and do normal activities. ACC deaminase enzyme was found to increase tap and lateral root elongation and provides tolerance against heavy metals and salinity in Arabidopsis (Glick et al., 2007; Sharma et al., 2016; Wintermans et al., 2016).

Early root system analysis used in this study covers a phase where bacteria are active and contributes to plant growth. Besides, an in-depth observation can be obtained without environmental fluctuations (light, temperature, etc.) more commonly emerging in the later growth stages (anthesis, maturity, etc.). Therefore, the aims of this study were; 1) to evaluate the effects of three different rhizobacteria species that synthesize ACC deaminase (Pseudomonas agarici, Arthrobacter agilis, and Brevibacillus choshinensis), on the root development and architectures of two different bread wheat varieties (Gerek 79 and Bezostaja 1); 2) to determine the root development differences in the early stage when the bacteria are active, and 3) to determine appropriate bacteria race for enhanced root development at the seedling stage.

\section{MATERIAL AND METHOD}

This study was carried out in Siirt University, Faculty of Agriculture, Department of Agricultural Biotechnology Laboratory. Bread wheat varieties Gerek 79 and Bezostaja 1 were used to screen root development differences. Three bacteria species; Pseudomonas agarici (TV24C), Arthrobacter agilis (TV126C), and Brevibacillus choshinensis (TV53D) were used as the source of ACC deaminase synthesis (Table 1). 
Table 1. Variety and bacteria abbreviations used in the study.

Çizelge 1. Çalışmada kullanılan çeşit ve bakteri kısaltmaları.

\begin{tabular}{ll|ll}
\hline Bezostaja 1 & Abbreviation & Gerek 79 & Abbreviation \\
\hline Bezostaja 1+ TV126C & Bez_126C & Gerek 79 + TV126C & Ger_126C \\
Bezostaja 1+ TV24C & Bez_24C & Gerek 79 + TV24C & Ger_24C \\
Bezostaja 1+ TV53D & Bez_53D & Gerek 79 + TV53D & Ger_53D \\
\hline
\end{tabular}

\section{Bacteria Inoculation}

Bacteria were taken from previously prepared stock cultures and transferred to nutrient broth medium and allowed to grow in this medium until reaching OD $600=0.02$ concentration. Concentration was measured with Multiskan GO (Thermo Fisher Scientific, USA). Liquid bacteria culture is used for seed inoculation. The inoculation was carried out for three hours at room temperature. Thus, the seeds were swelled and inoculated with bacterial culture. Inoculated seeds were dried under sterile conditions and stored for use in germination studies. Seed inoculation was checked by testing the dried seeds on a growth medium.

\section{Sowing Seeds}

The sterilized seeds were inoculated with rhizobacteria, dried, and imbibed into Petri dishes for 24 hours for homogenous germination. Seeds with homogenous germination were transplanted into the germination papers $(40 \times 40 \mathrm{~cm})$ covered with PVC plates and placed in containers filled with $20 \mathrm{~cm}$ water. Seedling growth was ensured by keeping a sufficient amount of water in the containers. Details of the PVC plate system are given in Hohn (2016).

\section{Analysis of Root Parameters}

In the study, early-stage (Z15) seminal root development (Zadoks et al. 1974) was analyzed in the PVC plates + germination paper system (modified cigar roll method) (Hohn, 2016). PVC plates were removed at the end of the $15^{\text {th }}$ day and images were taken at 300 DPI resolution with a handheld document scanner (ISCAN Portable Handheld Scanner). Images were analyzed using ImageJ image analysis software (imagej.nih.gov, Rueden et al. 2017). As a result of the analysis, total root length, number of embryonic (seminal) roots, the longest root length, and root growth angles were measured. Root growth angle was calculated by measuring the growth angle between the $2^{\text {nd }}$ level seminal roots that developed just after the first embryonic root.

\section{Statistical Analysis}

The experiment was conducted as three replications and 4 plants per replication. The data obtained were subjected to variance analysis (ANOVA) with Statistix 10 (Analytical Software; Tallahassee, FL, USA) software according to the "Factorial Design" and the differences between the application groups were determined with the Least Significant Difference (LSD) Multiple Comparison Test. Besides, the "compare with the best" function of the multiple comparison test was used to find the best bacteria $\mathrm{x}$ variety interaction.

\section{RESULTS AND DISCUSSION}

As a result of the study, germination problems or infections were observed in some bacteria applications, and some plants showing abnormal growth in Ger_53D and Ger_126C were eliminated. As a result of bacterial applications, a statistically significant difference was determined between wheat varieties and bacterial species according to the analysis of variance (ANOVA) in terms of total root length and root growth angle $(p<0.05)$, but no statistically significant difference was found in the longest root length.

\section{Total Root Length}

The effect of bacterial inoculation on the total root length of bread wheat varieties was significant. Variety, bacteria, and variety $x$ bacteria interactions significantly affected the total root length $(p<0.05)$. The mean total root length of Gerek $79(82.4 \mathrm{~cm})$ was higher than that of Bezostaja $1(54.35 \mathrm{~cm})$. When the effects of bacterial applications on the total root length on Bezostaja 1 were examined, Bez_126C had the longest root length (62.8 $\mathrm{cm})$ and Bez_53D had the shortest with $47.1 \mathrm{~cm}$. On the other hand, Ger_53D $(95.38 \mathrm{~cm})$ had the longest total root length while Ger_24C and Ger_126C had the shortest values in Gerek 79 bacteria applications (Table 2). This result showed that variation due to genetic differences between varieties was more than differences caused by bacterial species and each variety is affected by bacterial applications at different levels. Responses of each variety to three different bacteria were unique and seemed completely different from each other (Gerek 79 and 
Bezostaja 1). This difference highlights the importance of genotypic characteristics and high heritability in seedling root development. According to the Least Significant Difference (LSD) analysis, three main groups were obtained in the total root length between control groups, bacterial applications, and varieties (Table 2).

Table 2. The effect of bacterial inoculation on the total root length of bread wheat varieties.

Çizelge 2. Bakteri inokülasyonunun ekmeklik buğday çeşitlerinin toplam kök uzunluğuna etkisi.

\begin{tabular}{llll}
\hline \multirow{2}{*}{ Applications } & \multicolumn{2}{c}{ Varieties (cm) } & Mean \\
\cline { 2 - 4 } & Bezostaja 1 & Gerek 79 & 68.1 \\
Control & $54.5 \pm 4.4 \mathrm{bc}$ & $81.6 \pm 5.6 \mathrm{a}$ & 64.7 \\
1. Bacteria 24C & $53.0 \pm 5.6 \mathrm{bc}$ & $76.3 \pm 4.4 \mathrm{a}$ & 71.3 \\
2. Bacteria 53D & $47.1 \pm 5.6 \mathrm{C}$ & $95.4 \pm 14.9 \mathrm{a}$ & 69.6 \\
3. Bacteria 126C & $62.8 \pm 7.5 \mathrm{abc}$ & $76.3 \pm 10.6 \mathrm{ab}$ & 68.4 \\
\hline Mean & $54.4 \mathrm{~B}$ & $82.4 \mathrm{~A}$ & \\
\hline
\end{tabular}

*: Differences between means with the same letter are not statistically significant, $\mathrm{P}<0.05$.

\section{The Longest Root Length}

Although no statistically significant difference was observed in the longest root length according to variance analysis, Ger_53D $(28.99 \mathrm{~cm})$ had the longest root, and Bez_53D $(19.71 \mathrm{~cm})$ had the shortest root length (Table 3). Shaharoona et al. (2006) reported that ACC deaminase activity promotes nodule formation as well as root and stem development in maize. In a similar study, Contesto et al. (2008) found that ACC deaminase activity positively affects root and root hair length in Arabidopsis. Similarly, in this study, the root length was longer in seeds inoculated with bacteria. The Bez_53D generally had the least developed root system. Opposite responses of two varieties to the same bacteria application (53D) are worth further evaluation. The contrasting responses make plant $\mathrm{x}$ rhizobacteria interactions far more complex than a simple symbiosis and need to be tested on large-scale experiments. The plasticity (Ehdaie et al. 2012) of the root system may have affected varieties' responses to bacterial applications. The LSD test did not reveal any grouping for the longest root length and significant differences were observed only between varieties and applications. Statistically significant differences were observed only among Bez_126C-Bezostaja, Bez_53D-Bez_126C, and between Ger_53D-Ger_24C (Table 4).

Table 3. The effect of bacterial inoculation on the longest root length in bread wheat varieties.

Çizelge 3. Bakteriyel inokülasyonunun ekmeklik buğday çeşitlerinde en uzun kök uzunluğuna etkisi.

\begin{tabular}{llcc}
\hline \multirow{2}{*}{ Application } & \multicolumn{2}{c}{ Varieties (cm) } & \multirow{2}{*}{ Bacteria mean (cm) } \\
\cline { 2 - 4 } & Bezostaja 1 & Gerek 79 & 21.60 \\
Control & $20.07 \pm 1.6$ & $23.12 \pm 2.12$ & 22.87 \\
1. Bacteria 24C & $22.60 \pm 2.12$ & $23.15 \pm 1.66$ & 24.35 \\
2. Bacteria 53D & $19.71 \pm 2.12$ & $28.99 \pm 5.63$ & 24.31 \\
3. Bacteria 126C & $26.85 \pm 2.84$ & $21.76 \pm 4.01$ & 23.29 \\
\hline Variety mean & 22.30 & 24.26 & \\
\hline
\end{tabular}

Table 4. LSD all-pairwise comparison test of the longest root length.

Çizelge 4. En uzun kök uzunluğu LSD çoklu karşılaştırma testi sonuçları.

\begin{tabular}{|c|c|c|c|c|c|c|c|c|}
\hline Genotype & Mean-cm & Bezostaja 1 & Bez 126C & Bez 24C & Bez 53D & Gerek 79 & Ger $126 C$ & Ger 24C \\
\hline Bezostaja 1 & 20.072 & & & & & & & \\
\hline Bez_126C & 26.852 & $6.779 *$ & & & & & & \\
\hline Bez_24C & 22.658 & 2.586 & 4.193 & & & & & \\
\hline Bez_53D & 19.714 & 0.358 & $7.137^{*}$ & 2.944 & & & & \\
\hline Gerek 79 & 23.119 & 3.046 & 3.733 & 0.461 & 3.405 & & & \\
\hline Ger_126C & 21.756 & 1.684 & 5.096 & 0.902 & 2.042 & 1.363 & & \\
\hline Ger_24C & 23.151 & 3.078 & 3.701 & 0.492 & 3.436 & 0.032 & 1.394 & \\
\hline Ger_53D & 28.988 & 8.915 & 2.136 & 6.33 & 9.273 & 5.869 & 7.232 & $5.837^{*}$ \\
\hline $\begin{array}{l}\text { Alpha: } 0.05 \\
\text { Critical T Value: } 2.04\end{array}$ & $\begin{array}{l}\text { Standard E } \\
\text { Critical Val }\end{array}$ & $\begin{array}{l}\text { ror for Com } \\
\text { e for Comp }\end{array}$ & $\begin{array}{l}\text { arison: } 2.34 \\
\text { ison: } 4.7800\end{array}$ & $\begin{array}{l}\text { to } 6.5695 \\
13.399\end{array}$ & & & & \\
\hline
\end{tabular}

*: Significant at $\mathrm{P}<0.01$.

\section{Root Growth Angle}

The effects of variety, bacteria and variety $\mathrm{x}$ bacteria interactions for root growth angle were significant $(p<0.01)$. When the mean root growth angles were examined, the widest (horizontal rooting) root growth angle was seen in Bez_126C, while other Bezostaja 1 applications had similar values (104.2-90.7). Much narrower root growth angles $\left(73.1-59.5^{\circ}\right)$ were detected in Gerek 79 and bacterial applications in this variety. The widest root 
growth angle was observed in Bez_126C and Ger_24C in each variety, and the effect of bacterial inoculation on root growth angle was significant (Table 5). Shahzad et al. (2008) found that ACC deaminase activity was effective in the root architecture and biomass of chickpea (Cicer arietinum), and Schwartz et al. (2013) reported an increase in root size, lateral root formation, and nodule development in pea (Pisum sativum). In this study, there was a wide variation between varieties, possibly due to genetic differences, and within the varieties, due to bacteria inoculation. These results are promising for re-defining root development terms in established varieties. Bacteria inoculation seems to be effective on root growth angle and it may improve drought tolerance by promoting deep root formation (Uga et al., 2011; Lindh et al., 2014).

Table 5. The effect of bacterial inoculation on root growth angle in bread wheat varieties.

Çizelge 5. Bakteri inokülasyonunun ekmeklik buğday çeşitlerinde kök büyüme açısına etkisi.

\begin{tabular}{llll}
\hline \multirow{2}{*}{ Application } & \multicolumn{2}{c}{ Varieties } & Bacteria mean ( \\
\cline { 2 - 4 } & Bezostaja 1 & Gerek 79 & 81.86 \\
\hline Control & $90.67 \pm 4.46$ & $73.05 \pm 5.26$ & 91.90 \\
1. Bacteria 24C & $100.68 \pm 5.26$ & $83.12 \pm 4.04$ & 77.93 \\
2. Bacteria 53D & $96.33 \pm 5.26$ & $59.53 \pm 13.76$ & 87.35 \\
3. Bacteria 126C & $104.21 \pm 6.97$ & $70.49 \pm 9.81$ & 84.76 \\
\hline Variety mean & 97.97 & 71.54 & \\
\hline
\end{tabular}

In a comparative analysis, significant root growth angle differences were observed between all Bezostaja 1 and all Gerek 79 bacteria applications. There were contrasting differences between bacteria applications in each variety. The 126C, 24C, and 53D had significantly different effects on Bezostaja 1 and Gerek 79 (Table 6). Bezostaja 1 had a mean root growth angle of $97.97^{\circ}$ while Gerek 79 had $71.55^{\circ}$ among all applications and control. The differences in mean root growth angle may have been due to genetic and application factors.

Table 6. LSD all-pairwise comparison test of the root growth angle $\left(^{\circ}\right)$ between varieties.

Çizelge 6. Kök büyüme açısı LSD çoklu karşılaştırma testi sonuçları.

\begin{tabular}{|c|c|c|c|c|c|c|c|c|c|}
\hline Variety/Bacteria & Mean $^{\circ}$ & Bez_126C & Bez_24C & Bez_53D & Bezostaja 1 & Ger_126C & Ger_24C & Ger_53D & Gerek 79 \\
\hline Bez_126C & 104.21 & & & & & & & & \\
\hline Bez_24C & 100.68 & 3.52 & & & & & & & \\
\hline Bez_53D & 96.33 & 7.87 & 4.35 & & & & & & \\
\hline Bezostaja 1 & 90.67 & 13.54 & 10.02 & 5.67 & & & & & \\
\hline Ger_126C & 70.49 & $33.72^{*}$ & $30.19 *$ & $25.84^{*}$ & 20.18 & & & & \\
\hline Ger_24C & 83.12 & $21.08^{*}$ & $17.56^{*}$ & 13.21 & 7.54 & 12.64 & & & \\
\hline Ger_53D & 59.53 & $44.68^{*}$ & 41.15* & $36.80^{*}$ & $31.14^{*}$ & 10.96 & 59.53 & 23.59 & \\
\hline Gerek 79 & 73.05 & 31.15* & 27.63* & 23.28* & $17.61^{*}$ & 2.57 & 73.05 & 10.07 & 13.52 \\
\hline Alpha: & 0.05 & \multirow{2}{*}{\multicolumn{8}{|c|}{$\begin{array}{l}\text { Standard Error for Comparison: } 6.0181 \text { to } 16.003 \\
\text { Critical Value for Comparison: } 12.291 \text { to } 32.683\end{array}$}} \\
\hline Critical T Value: & 2.042 & & & & & & & & \\
\hline
\end{tabular}

To observe the variation caused by bacteria applications, a "compare with the best value" test was conducted between varieties and applications. The angle difference of $-33.72^{\circ},-21.08^{\circ},-44.68^{\circ}$, and $-31.15^{\circ}$ with Bez $126 \mathrm{C}$ was calculated with Ger_126C, Ger_24C, Ger_53D, and Ger_53D were obtained, respectively (Table 7).

Table 7. HSU'S "Compare with the Best Value" Multiple Comparison Analysis.

Çizelge 7. "En İyi Değerle Karşılaştır" HSU Çoklu Karşılaştırma Analizi sonuçları.

\begin{tabular}{lllll}
\hline Variety & Mean $^{\circ}$ & Lower limit & Difference $^{\circ}$ & Upper limit $^{\circ}$ \\
\hline Bez_126C & 104.21 & -16.96 & 3.52 & 23.47 \\
Bez_24C & 100.68 & -23.47 & -3.52 & 16.96 \\
Bez_53D & 96.33 & -27.82 & -7.87 & 12.61 \\
Bezostaja 1 & 90.67 & -33.1 & -13.54 & 6.73 \\
Ger_126C & 70.49 & -61.3 & $\mathbf{- 3 3 . 7 2 *}$ & 0 \\
Ger_24C & 83.12 & -40.65 & $\mathbf{- 2 1 . 0 8 ^ { * }}$ & 0 \\
Ger_53D & 59.53 & -80.86 & $\mathbf{- 4 4 . 6 8 ^ { * }}$ & 0 \\
Gerek 79 & 73.05 & -51.1 & $\mathbf{- 3 1 . 1 5 *}$ & 0 \\
\hline Alpha: & 0.05 & Standard Error for Comparison: 8.059 to 14.91 \\
\hline Critical D Value: & Varies & Critical Value for Comparison: 19.95 to 32.56 \\
\hline
\end{tabular}

*: Significant at $\mathrm{P}<0.01$. 
The Bez_126C showed the greatest trend for horizontal root growth while Ger_53D showed the trend for more vertical root growth. Gerek 79 is reported to be a drought-tolerant variety (Çekiç, 2007; Bayram et al., 2015; Ayrancl et al., 2017). The presence of narrow-root growth angle and vertical growth trend supports that the roots may reach deeper soil profiles. On the other hand, Bezostaja 1 is reported to be more sensitive to drought (Çekiç, 2007; Bayram et al., 2015). According to root growth angle values, Bezostaja 1 had a wider root growth angle compared to Gerek 79. The complex interactions between each variety and bacterial inoculations are worth further evaluations to breed root ideotypes with tolerance to drought or nutrient-limited conditions (Lynch, 213; Gouache et al. 2015).

\section{CONCLUSION}

It has been known for a long time that bacteria break down the ACC precursor (deaminase) by synthesizing ACC deaminase causing ethylene biosynthesis to cease or decrease (Gontia-Mishra et al., 2014; Govindasamy et al., 2008 and 2009). It has also been reported that this mechanism prevents the formation of stress, allows the synthesis of hormones such as auxin, and increases root growth (Ali et al., 2014; Carlos et al., 2016). In this study, three different bacteria species known to synthesize ACC deaminase were tested in two different bread wheat varieties with different adaptation capacities. Significant but contrasting interactions were obtained. It is thought that it would be beneficial to inoculate plants at regular intervals from the leaf or root collar as well as from the seed. This study, which reveals the root structure of bread wheat and the effect of PGPR on the root system, is a prelude to understanding the relationships between the plant root system and beneficial bacteria.

\section{CONFLICT OF INTEREST}

The authors declare that there are no conflicts of interest related to this article.

\section{DECLARATION OF AUTHOR CONTRIBUTION}

$\mathrm{HB}$ and $\mathrm{YB}$ designed and performed the experiments, analyzed data, and wrote the manuscript; $\mathrm{MS}, \mathrm{FC}$ and $\mathrm{BI}$ provided feedback and run statistical analysis. All authors read and approved the final manuscript.

\section{ACKNOWLEDGMENT}

This study was supported by a scientific research project numbered SiÜZiR-64 of the Siirt University. The authors are grateful to Dr. Sara Yasemin and Semih Acikbas for proofreading and inputs.

\section{REFERENCES}

Ali, S. Z., Sandhya, V., \& Rao, L. V. (2014). Isolation and characterization of drought-tolerant ACC deaminase and exopolysaccharide-producing fluorescent Pseudomonas sp. Annals of Microbiology, 64, 493-502.

Anderson, W. K. (2010). Closing the gap between actual and potential yield of rainfed wheat. The impacts of environment, management and cultivar. Field Crops Research, 116(1-2), 14-22.

Ayrancl, R., Bayram, S., \& Soylu, S. (2017). The Response on the Drought Stress Yield and Phenological Properties of Bread Wheat Genotypes in Grain Filling Stage. Tarla Bitkileri Merkez Araştırma Enstitüsü Dergisi, 26,112-118.

Bayram, S., Öztürk, A., \& Aydın, M. (2015). Seedling survival as a criterion of resistance to early drought in bread wheat genotypes. Turkish Journal of Nature and Science, 4(2), 30-35.

Biçer, Ş., Erdinç, Ç., \& Çömlekçioğlu, N. (2020). The effects of root bacteria (PGPR) and arbuscular mycorrhizal fungi (AMF) inoculation on plant growth and yield properties at different irrigation levels in cucumber. Uluslararası Tarım ve Yaban Hayatı Bilimleri Dergisi, 6(1), 8-20.

Carlos, M. H. J., Stefani, P. V. Y., Janette, A. M., Melani, M. S. S., \& Gabriela, P. O. (2016) Assessing the effects of heavy metals in ACC deaminase and IAA production on plant growth-promoting bacteria. Microbiological Research, 188, 53-61.

Contesto, C., Desbrosses, G., Lefoulon, C., Bena, G., Borel, F., Galland, M., Gamet, L., Varoquaux, F., \& Touraine, B. (2008). Effects of rhizobacterial ACC deaminase activity on Arabidopsis indicate that ethylene mediates local root responses to plant growth-promoting rhizobacteria. Plant Science, 175, 178-189. 
Çekiç, C. Y. (2007) A study on physiological parameters which can be used as selection criteria in breeding wheat (Triticum aestivum L.) for drought resistance. Ankara University Graduate School of Natural and Applied Sciences, Soil Science and Plant Nutrition Program.

Döös, B. R. (2002). Population growth and loss of arable land. Global Environmental Change, 12(4), 303-311.

Ehdaie, B., Layne, A. P., \& Waines, J. G. (2012). Root system plasticity to drought influences grain yield in bread wheat. Euphytica, 186(1), 219-232.

FAOSTAT. (2019). Food, Agriculture Organization of the United, Nations. Available from, http://faostat.fao.org/default.aspx. Accessed date: May 04, 2021.

Gouache, D., Bogard, M., Thepot, S., Pegard, M., Le Bris, X., \& Deswarte, J. C. (2015). From ideotypes to genotypes: approaches to adapt wheat phenology to climate change. Procedia Environmental Sciences, 29, 34-35.

Glick, B. R., Cheng, Z., Czarny, J., \& Duan, J. (2007). Promotion of plant growth by ACC deaminase-producing soil bacteria. European Journal of Plant Pathology, 119(3), 329-339.

Gontia-Mishra, I., Sasidharan, S., \& Tiwari, S. (2014). Recent developments in use of 1-aminocyclopropane-1-carboxylate (ACC) deaminase for conferring tolerance to biotic and abiotic stress. Biotechnology Letters, 36, 889-898.

Govindasamy, V., Senthilkumar, M., Gaikwad, K., \& Annapurna, K. (2008). Isolation and characterization of ACC deaminase gene from two plant growth-promoting rhizobacteria. Current Microbiology, 57, 312-317.

Govindasamy, V., Senthilkumar, M., Mageshwaran, V., \& Annapurna, K. (2009). Detection and characterization of ACC deaminase in plant growth promoting rhizobacteria. Journal of Plant Biochemistry and Biotechnology 18, 71-76.

Hawkesford, M. J., Araus, J. L., Park, R., Calderini, D., Miralles, D., Shen, T., \& Parry, M. A. J. (2013). Prospects of doubling global wheat yields. Food and Energy Security, 2(1), 34-48.

Hohn, C. E. (2016). Discovery and Verification of Quantitative Trait Loci (QTLs) for Seminal Root Traits and Insights Into Root to Shoot Tradeoffs in Hexaploid Wheat (Triticum aestivum L.). University of California Riverside. Riverside, CA, USA.

Lindh, M., Zhang, L., Falster, D., Franklin, O., \& Brännström, A. (2014). Plant diversity and drought: the role of deep roots. Ecological modelling, 290, 85-93.

Lynch, J. P. (2013). Steep, cheap and deep: an ideotype to optimize water and N acquisition by maize root systems. Annals of Botany, 112(2), 347-357.

Manschadi, A. M., Christopher, J., deVoil, P., \& Hammer, G. L. (2006). The role of root architectural traits in adaptation of wheat to water-limited environments. Functional Plant Biology, 33(9), 823-837.

Passioura, J. B. (1983). Roots and drought resistance. Agricultural Water Management, 7(1-3), 265-280.

Passioura, J. B. (2012). Phenotyping for drought tolerance in grain crops: when is it useful to breeders? Functional Plant Biology, 39(10-11), 851-859.

Reeves, T. G., Thomas, G., \& Ramsay, G. (2016). Save and grow in practice: maize, rice, wheat-a guide to sustainable cereal production. UN Food and Agriculture Organization, Rome.

Reynolds, M., Dreccer, F., \& Trethowan, R. (2007). Drought-adaptive traits derived from wheat wild relatives and landraces. Journal of Experimental Botany, 58(2), 177-186.

Richards, R. A., \& Passioura, J. B. (1981). Seminal root morphology and water use of wheat II. Genetic Variation 1. Crop Science, 21(2), 253-255.

Rueden, C. T., Schindelin, J., Hiner, M. C., DeZonia, B. E., Walter, A. E., Arena, E. T., \& Eliceiri, K. W. (2017). ImageJ2: ImageJ for the next generation of scientific image data. BMC Bioinformatics, 18(1), 529.

Schwartz, A. R., Ortiz, I., Maymon, M., Herbold, C. W., Fujishige, N. A., Vijanderan, J. A., Villella, W., Hanamoto, K., Diener, A., Sanders, E. R., \& DeMason, D. A. (2013). Bacillus simplex-a little known PGPB with anti-fungal activity-alters pea legume root architecture and nodule morphology when co-inoculated with Rhizobium leguminosarum bv. viciae. Agronomy, 3(4), 595-620.

Shaharoona, B., Arshad, M., \& Zahir, Z. A. (2006). Effect of plant growth promoting rhizobacteria containing ACC-deaminase on maize (Zea mays L.) growth under axenic conditions and on nodulation in mung bean (Vigna radiata L.). Letters in Applied Microbiology, 42, 155-159.

Shahzad, S. M., Khalid, A., Arshad, M., Khalid, M., \& Mehboob, I. (2008). Integrated use of plant growth promoting bacteria and p-enriched compost for improving growth, yield and nodulation of chickpea. Pakistan Journal of Botany, 40, 17351741. 
Sharma, S., Kulkarni, J., \& Jha, B. (2016). Halotolerant rhizobacteria promote growth and enhance salinity tolerance in peanut. Frontiers in Microbiology, 7, 11.

Trnka, M., Hlavinka, P., \& Semenov, M. A. (2015). Adaptation options for wheat in Europe will be limited by increased adverse weather events under climate change. Journal of the Royal Society Interface, 12(112).

Uga, Y., Okuno, K., \& Yano, M. (2011). Dro1, a major QTL involved in deep rooting of rice under upland field conditions. Journal of Experimental Botany, 62(8), 2485-2494.

Weaver, J. E. (1926). Root development of field crops. McGRAW-Hill Book Company, INC. New York.

Wintermans, P. C. A., Bakker, P., \& Pieterse, C. M. J. (2016). Natural genetic variation in Arabidopsis for responsiveness to plant growth-promoting rhizobacteria. Plant Molecular Biology, 90(6), 623-634.

Zadoks, J. C., Chang, T. T., \& Konzak, C. F. (1974). A decimal code for the growth stages of cereals. Weed Research, 14(6), 415421. 